\title{
Pairing Coconut and Candlenut Oil as Feed Supplement in Low Protein Diet with Addition Se on Feed Efficiency of Red Nile Fish (Oreochromis Niloticus)
}

\author{
K Haetami $^{1, *}$, Junianto ${ }^{1}$, Abun ${ }^{2}$ \\ ${ }^{1}$ Laboratory of Aquaculture, Faculty of Fisheries and Marine Science, Universitas Padjadjaran, Bandung, \\ Indonesia \\ ${ }^{2}$ Department of Nutrition, Faculty of Animal Husbandry, Universitas Padjadjaran, Bandung, Indonesia \\ *Corresponding author.Email: kiki.haetami@unpad.ac.id
}

\begin{abstract}
Nutritional Balance in feed is critical to improve the efficiency of feed. The use of oil in omnivore fish can serve as a spare protein-energy provider in addition to carbohydrates. Not only is the adequacy of the quantity and quality of protein that must be guaranteed, often the energy value is not as predicted, so the addition of high-calorie ingredients is important. Efforts to replace some of the protein functions as an energy source, by feed oil supplements from pairing coconut flesh as saturated fat combined with candlenuts as unsaturated fat, with added of trace element Se, thus improving the optimum use of protein in freshwater fish.This study aims toget the ratio and type of fat (saturated and unsaturated) of feed formula (low protein 28\%) with selenium supplementation, compared with high protein (32\%), which can increase feed efficiency of red nile tilapia (Oreochromis niloticus) fingerling phase. The preparation stage found that pairing coconut fat supplements were dominated by saturated fatty acid as lauric (42.67\%). In contrast, candlenut fats contained unsaturated fatty acids, linoleic $(34.4 \%)$, and oleic $(48.99 \%)$, so the use of candlenut oil $(0 \%$, $2 \%$ and $4 \%$ ) can increase the ratio of unsaturated fatty acids in the feed. Treatments consist of $6 x 3$ with Completely Randomized Design by a ratio of the source of unsaturated fat and saturated fat with mineral addition Se. R1was low protein feed without supplements; R2 and R3were low protein feed containing ratio of unsaturated-saturated fat 1:1 (mixture of oil were $2 \%$ of each) without and with addition of Se, and then R4 1:2 (coconut oil); 2:1 (candlenut oil) and R6 high protein without of fat supplements 2:3, produces normal physiological (hematologic and digestive) images for tilapia health.The Result showed that coconut and candlenut mixed-oil $2 \%$ of each with addition of Se $0.15 \mathrm{ppm}$, was the best feed efficiency in tilapia ranged from 50.14-57.93\% and protein efficiency ratio $1.72-2.06$.
\end{abstract}

Keywords: Coconut Oil, Candlenut Oil, Nutritional Balance, Red Nile

\section{INTRODUCTION}

Fat and fatty acids, as part of the lipid, can serve as a precious protein-sparing for growth, as a fuel to generate metabolic energy in fish muscles. Fat is a nutrient source of energy that can be obtained from feed material, such as soybean meal or by-product food processing such as corn bran and wheat bran (pollard), some of the oil content is lost. The use of feed supplement visible fat source is necessary to achieve the balance of fat and its essential components. The raw material for vegetable oil comes from various types o plants such as oil palm, soybean, coconut, corn, beans, grains, and so on. Every vegetable oil has properties and its own characteristics, which are largely determined by the structure of fatty acids in the triglyceride sequence.

Coconut plant is source of saturated fatty acids, both of palm oil and other coconut product. Lauric acid in coconut oil has antiviral, antiprotozoal, and antibacterial 
properties, and together with that can increase the body's metabolism. The benefits of coconut oil are stable at room temperature and resistant to oxidative rancidity [1]. Coconut plants from Cocos nucifera are currently used as coconut milk in household scale and can be widely found as market waste, one of which is coconut husk (pairing coconut).The candlenut crop (Alleurites mollucana) belongs to the Euphorbiaceae class, known as a hardwood crop commodity in the tropics. The oleic unsaturated fatty acids dominate the fatty acids contained in the candlenut oil, $48.5 \%$ linoleic $(\omega 6)$, and $28.5 \%$ linolenic ( $\omega 3)$ [2]. Similarly, coconut (Cocos nucifera), as a tropical plant of Palmae species is known to contain many benefits, especially coconut meat, along with its waste (skin of flesh and coconut water).

The addition of $5-10 \%$ peanut oil can improve feed conversion with a lower feed efficiency ratio [3]. The high fat is also associated with decreased availability of cations in the intestine and increased fat content in the body's cells causing oxidative stress [4]. Given that the use of fat sources with mineral supplementation is considered necessary to increase the benefits of fat in the diet. Minerals can enhance attachment (gelation or chelate) through the formation of bridges of salt between molecules and their existence play a role in various processes.

Selenium (Se) is an essential trace element in various reactions and regulators of energy metabolism because its function can regulate the esterification of fatty acids and the pentose phosphate pathway (PPP) [5]. Metalloenzyme is important in the oxidation reaction of the reduction and function of the thyroid hormone [6].

Effective use of fats and selenium (quantitatively) needs to be supported with information on the characteristics of energy sources that are expected to provide benefits to improve the efficiency of the Nile (Oreochromis niloticus Lin.) fish feed. Feed fat is needed as a source of essential fatty acids. Several fatty acids such as monoenoic (oleic fatty acid) and dienoic (linoleic and linolenic fatty acids) are mainly required by fish to synthesize some fatty acids by elongation of the carbon chain and the addition of double bonds (desaturation) [7]. Essential fatty acids required by tilapia are of the type linoleic acid $(\omega 6)$ of $0.5-1 \%$ [8].

The addition of fat supplements will increase the calorie $8.5 \mathrm{kcal} / \mathrm{g}$ of fat. The increase of energy within certain limits can cause a positive effect of protein sparring (substitution of some proteins in its function as a provider of energy), so it is expected that fat supplements in low protein resulting in the same growth and efficiency as standard feeding.

\section{MATERIALS AND METHODS}

The research includes the preparation stage consisting of extraction, then biological tests to determine the value of benefits to growth, and feed efficiency on the tilapia fish with an initial length of about 5-6 cm and weight of about 10 grams. The research materials used arecandlenutseed, coconut, fingerling fish, feed raw material, and commercial feed. The chemicals used include chemicals for fat extraction (n-hexane), proximate analysis, and hematologic blood test. Feed formulation consists of soybean flour, bran, fish meal, coconut meal, cornflour and polar, and premix. The maintenance container used is an aquarium sealed with the size of each boxof $40 \times 40 \times 35 \mathrm{~cm} 3$ of 18 units, which is equipped with an aerator and heater. Aeration source using a blower and for acclimation purposes used four pieces of fiber size $1 \mathrm{~m} 3$.

The Research was conducted experimentally using a Completely Randomized Design of 6 treatments and three replications. Basal feed protein R1 $28 \%$ with treatment R2, R3 (2\% candlenut oil mixture and $2 \%$ coconut extract), and R4, R5 (4\% each and 4\% coconut extract) and R6 (Standard Feed, Protein 32\%). Treatments consist of $6 \times 3$ with Completely Randomized Design by the ratio of unsaturated fat and saturated fat supplement Se. R1low protein feed $(28 \%)$ without supplements; R2 and R3 low protein feed containing ratio of unsaturated-saturated fat 1:1 (mixture of extract) without and with addition of Se, and then R4 1:2 (coconut extract); 2 : 1 (candlenutextract) and R6 high protein without of fat supplements $2: 3$, normal physiological produces (digestive) images for tilapia health. R3-5 (coconut oil, candlenut or mixed) plus Selenium, formulated by the same protein content $( \pm 28 \%)$. The R1 $( \pm 28 \%$ protein) and R6 (protein $\pm 32 \%$ ) were treated without fat supplements and $\mathrm{Se}$, and all treatments (R16) were formulated iso-energy.

\section{RESULTS AND DISCUSSION}

Seed size and fingerling require higher protein, fat, vitamin nutrients for muscle development, internal organs and bones. Whereas in larger (sub-adult) fish, the protein requirement for growth is less because the metabolic rate is slower. Similarly to the feed conversion ratio and protein efficiency (protein efficiency ratio), the increase in fish weight is negatively correlated with the amount of feed protein given [9].

\subsection{Feed Conversion}

The mean of conversion and Duncan Test results are presented in Table 1. 
Table1. Duncan test results influence of treatment on giving feed conversion of nile nirvana stadium fingerling

\begin{tabular}{|c|c|c|}
\hline Treatment*) & $\begin{array}{c}\text { Amount of } \\
\text { Feed } \\
\text { (gram) }\end{array}$ & $\begin{array}{c}\left.\text { Feed Conversion }^{* *}\right) \\
\text { (Index) }\end{array}$ \\
\hline$R_{1}$ & 42.41 & $1.99 \pm 0.019^{d}$ \\
\hline$R_{2}$ & 46.40 & $1.93 \pm 0.037^{c}$ \\
\hline$R_{3}$ & 48.62 & $1.78 \pm 0.044^{\mathrm{ab}}$ \\
\hline$R_{4}$ & 46.30 & $1.79 \pm 0.028^{\mathrm{b}}$ \\
\hline$R_{5}$ & 46.31 & $1.73 \pm 0.016^{\mathrm{a}}$ \\
\hline$R_{6}$ & 50.10 & $1.82 \pm 0.025^{\mathrm{b}}$ \\
\hline
\end{tabular}

${ }^{*} \mathrm{R} 1$ : without supplement (protein 28\%);

$\mathrm{R} 2$ : mix coconut-candlenut oil;

$\mathrm{R} 3$ : mix coconut-candlenut oil $+\mathrm{Se}$;

R4 : coconut oil + Se;

$\mathrm{R} 5$ : candlenutoil $+\mathrm{Se}$;

R6 : control feed (32\%).
**)The same superscripts letter to the column indicate no significant difference $(\mathrm{p}>0.05)$

Table 1 showed that R3 and R5 results in better feed conversion than other supplementation treatments without Se (R1 and R2) supplements. Feeding levels can be adjusted as needed, and setting the amount of feed can protect pellets from leaching in the water. R1 and R2 yield lower feed efficiency than other treatments, although according to 5\% dietary fat content (R1) can meet minimum fat requirements in most cultivation systems [10]. A Semi-purifid feed with $8 \%$ fat can save more protein than $4 \%$, but increasing fat up to $16 \%$ does not improve efficiency [11]. The treatments of R3, R4, and R5 each show no different conversion of feed, ranging from 1.73 to 1.78 . Although the growth of R3 fish, R5 was higher than R4 (Table 2), the three treatments resulted in no different conversion, efficiency and efficiency of feed protein. The content of unsaturated fatty acids (linoleat) R3 and R5 as needed (1\%) [8] compared to R4 $(0.36 \%)$.

Feeding rate by ad satiation of $4 \%$ fish weight/day with frequency of giving twice, with adjustment every week. This is consistent with the measurement of the rate of passage of the digestive. Treatmenttract (rate of passage) about 11-13 hours with a maximum feed consumption of $3.825-4.35 \% /$ day.

Table 2. Estimating Daily feed consumption (D).

\begin{tabular}{|l|c|c|c|c|c|c|c|}
\hline Estimate & $R_{1}$ & $R_{2}$ & $R_{3}$ & $R_{4}$ & $R_{5}$ & $R_{6}$ & Average \\
\hline$b$ & -0.079 & -0.081 & -0.091 & -0.082 & -0.092 & -0.094 & -0.086 \\
\hline $\mathrm{a}$ & 1.299 & 1.222 & 1.242 & 1.170 & 1.178 & 1.047 & 1.193 \\
\hline $\mathrm{k}$ & 0.079 & 0.081 & 0.091 & 0.082 & 0.092 & 0.094 & 0.086 \\
\hline Ao & 3.667 & 3.394 & 3.463 & 3.221 & 3.248 & 2.849 & 3.307 \\
\hline $\mathrm{t}$ & 13.921 & 13.596 & 12.071 & 13.474 & 11.950 & 11.736 & 12.791 \\
\hline $24 / \mathrm{t}$ & 1.724 & 1.765 & 1.988 & 1.781 & 2.008 & 2.045 & 1.885 \\
\hline $\mathrm{D}(\% \mathrm{bw} / \mathrm{d})$ & 4.215 & 3.995 & 4.591 & 3.825 & 4.350 & 3.884 & 4.143 \\
\hline
\end{tabular}

R1 : without supplement (protein 28\%);

$\mathrm{R} 2$ : mix coconut-candlenut oil;

$\mathrm{R} 3$ : mix coconut-candlenut oil $+\mathrm{Se}$;

R4: coconut oil +Se;

R5: candlenut oil $+\mathrm{Se}$;

R6: control feed 32\%).

\subsection{Feed efficiency, and protein efficiency ratio}

The ratio of saturated and unsaturated fatty acids treatment of R3 is 1: 1, whereas R5 has a ratio of $1: 2$ and R6 2: 3 which shows the content of unsaturated fatty acid more, so minimum requirement of linoleic fatty acid equal to $0.5 \%$ in all three treatments it can be fulfilled.
Table 3. Duncan test results influence of treatment on feed efficiency and protein eficiency ratio of nirvana nile stadium fingerling

\begin{tabular}{|c|c|c|}
\hline Treatment $^{*}$ & Feed Efficiency $^{* *}$ & \multicolumn{2}{|c|}{ Protein Efficiency Ratio ${ }^{* *}$} \\
\hline$R_{1}$ & $50,14 \pm 0,48^{a}$ & $1,79 \pm 0,02^{b}$ \\
\hline$R_{2}$ & $51,91 \pm 1,01^{b}$ & $1,85 \pm 0,04^{c}$ \\
\hline$R_{3}$ & $56.23 \pm 1,37^{c d}$ & $2,01 \pm 0,05^{d}$ \\
\hline$R_{4}$ & $55,99 \pm 0,87^{c d}$ & $2,00 \pm 0,03^{d}$ \\
\hline$R_{5}$ & $57,68 \pm 0,53^{d}$ & $2,06 \pm 0,02^{d}$ \\
\hline$R_{6}$ & $55.01 \pm 0,75^{c}$ & $1,72 \pm 0,02^{a}$ \\
\hline
\end{tabular}


${ }^{*} \mathrm{R} 1$ : without supplement (protein $28 \%$ );

$\mathrm{R} 2$ : mix coconut-candlenut oil;

$\mathrm{R} 3$ : mix coconut-candlenut oil $+\mathrm{Se}$;

$\mathrm{R} 4$ : coconut oil $+\mathrm{Se}$;

$\mathrm{R} 5$ : candlenutoil $+\mathrm{Se}$;

R6 : control feed (32\%).

$\left.{ }^{* *}\right)$ The same superscripts letter to the column indicate no significant difference $(\mathrm{p}>0.05)$

The treatments of R3, R4, and R5 each show no different feed efficiency of feed, ranging from $56.23 \%$ to $57.68 \%$. Although the growth of R3 fish, R5 was higher than $\mathrm{R} 4$, the three treatments resulted in no different efficiency and efficiency of feed protein. The content of unsaturated fatty acids (linoleate) R3 and R5 as needed $(0.5-1 \%)$ [8], compared to R4 $(0.36 \%)$. The results of the other research showed adecrease in the growth of Oreochomis aureus if dietary excess linoleic fatty acids [12]. Fatty acid requirement Nile tilapia is recommended no more than $0.5-1 \%$ range for 18: $2 \omega 6$ [13]. However, although R4 lacks linoleic fatty acids, the saturated coconut fatty acids contained therein are predominantly of lauric acid species, including medium-chain triglycerides (MCTs) having low melting points. The use of fat supplements (R3, R4, and R5) with Selenium mineral addition improves feed efficiency compared to without supplements. Fat is important as a protective nutrient (coating) in protein-lipid emulsions [14]. Most of the absorption of the fatty acids of the intestinal mucosa is circulated in the form of protein-lipid complexes stabilized by phospholipids. Unsaturated fatty acids as phospholipid components play an important role in poichyloterm animals at low temperatures. As for tilapia, the type of unsaturated fatty acids needed for freshwater fish in this tropical area is $\omega 6$ fatty acid or mixture. However, the source of PUFA essential fatty acids, easily oxidized due to alarge number of double bonds, as well as the volatile fatty acids. Hence the presence of selenium is significant in fat utilization, so R2 (without selenium) results in lower efficiency than R3 (with Se supplement). The saturated and unsaturated fatty acid ratio between $\mathrm{R} 2$ and $\mathrm{R} 3$ is the same (1: 1), with the contentlinoleateof $1.04 \%$ (Table 1).

Thus, the results of this study both of saturated fatty acids (R4), also of unsaturated-saturated ratio 1:1 of clear coconut and candlenut oils supplemented Se (R3) produce the same feed efficiency with high protein pellets (R6). The best efficiency, conversion, and feed protein efficiency results were generated by the dominance of unsaturated fatty acids (R5)and R3 with $2 \%$ coconut and $2 \%$ candlenut supplements. Better use of the fat mixture was also obtained from research results that coconut oil, fish oil and tallow mixes of $1.7 \%$ produced the best growth in trout [3].

The treatment of mixed visible fat $(1: 1)$ ratio and $\mathrm{Se}$ supplements (R3) has a higher feed efficiency than without of Se supplements (R2). Se mineral needed in small quantities, but has the ability to improve the efficiency, immunity, and quality of meat. Selenium is converted to selenomethionine and only a small part of selenomethionine is excreted through urine and feces. Glutathione, effectively binds S-containing compounds, amine groups, and secondary products to lipid oxidation breakdowns (aldehydes, ketones, and alcohols), during interacting with amino, protein, and vitamins [15]. Se mineral supplementation of $0.15 \mathrm{mg} / \mathrm{kg}$ of feed is effective and can improve conversion through the mechanism of glutathione peroxidase activityin reducing oxidation in [4].

Parameter of protein usage one of them is measured from the amount of weight increase of protein divided by protein given (Protein Efficiency Ratio). Fat and Se supplements on low-protein diet (R3, R4, R5) had a significantly higher PER (2.01-2.06) range than R2 (1.85), R1 (1, 79), and R6 (1.72). R6 which showed an effect inversely proportional to feed protein intake. Increased protein intake $(35 \%$ to $45 \%$, compared to $35 \%)$.

The use of vegetable oil, both candlenut oil (dienoic source), coconut oil (source of triglyceride medium) can be used as a supplement of energy sources other than protein (spare protein) for fish. The ratio of 1: 1 of both materials can meet the minimum requirement of dienoic acid by $0.5 \%$, and the linoleic/linolenic ratio $(\omega 3 / \omega 6)$ of 13 is sufficient for the essential fatty acids for tilapia seeds.

\section{CONCLUSION}

Conversion and efficiency of tilapia feed with candlenut nut supplement and $\mathrm{Se}$ is equal to 1.73 and $57.68 \%$, better than feed without the addition of Se. The Ratio of protein efficiency (REP) with $\mathrm{Se}$ and $4 \%$ fatsupplement from the oil of candlenut, coconut, or mixture is ranged2.01 - 2.06, and better than fish fed with highprotein $(32 \%)$ that is equal to 1.72 .

\section{REFERENCES}

[1] AliceH,LichtensteinLJ, AppelB, MichaelS, and CamethonM 2006 Diet and life style recommendations revision Scientific statement from the American Heart Association Nutrition Committee Circulation114: 82-96

[2] Haetami K, Abun, Rusmana D, and Mulyani Y 2016 Fats in products feed supplements and effect on retention of protein in nilem fish (Osteochilus hasseltii)Scientific Papers Series D. Animal Science Bucharest Rumania vol. LIX, pp 320-325

[3] AderoluAZ and Akinremi OA 2009Dietary effects of coconut oil and peanut oil in improving biochemical characteristics of Clarias gariepinusjuvenile Turkish Journal of Fisheries and Aquatic Sciences 9:105-110 
[4] A mirkolaieA, Karimzadeh J, and Kenari AA 2014 The effects of organic selenium on performance and oxidative level in rainbow trout (Oncorhynchus mykiss, Walbaum 1782. 2) fed a high-fat diet. Journal of Animal and Feed Science 23:90-96

[5] Miles, B. 2003. Amino Acid degradation. Article.

[6] Mc.GuireM and Beerman KA 2007 Nutritional Sciences, from fundamentals to food Thomson Higher Education. Bellmont. 610 pp.

[7] GurrMJ, HarwoodJL, and Frayen KN 2002. Lipid Biochemistry. 5-th Edition Blackwell Science Ltd. Blackwell Publishing Co. UK

[8] Tacon, AGJ 1986. The Nutritional of feeding of farmed fish and Shrimp FAO of The United Nations, Brazil

[9] Gao W, LiuYJ, TianLX, MaiKS, Liang GY, Yang HJ, and Huay MY 2011 Protein sparring capability of dietary lipid in herbivorous and omnivorous freshwater finfish: a comparative case study on grass carp and tilapia Aquaculture Nutrition 17:2-12

[10] Ng, WK and Chong W 2000An Overview of Lipid Nutrition with Emphasis on Alternative Lipid Sources in Tilapia FeedsSchool of Biological Sciences, University Sains Malaysia

[11] Hertramph J W and Pascual F P 2000. Handbook on Ingredients for Aquaculture Feeds. Kluwer Academic Publishers. London pp 506

[12] El-Husseiny OM, Abdul-AzizGM, GodaAM and Suloma A2010 Effect of altering linoleic acid and linolenic acid dietary levels and rations on the erformance and tissue fatty acids profiles of Nile tilapia Oreochromisniloticus fry. Aquaculture International. Oct Vol 8 Issue 6, p 1105-1119, 15p.7 Charts Article

[13] TakeuchiT, Watanabe $\mathrm{T}$ and Ogino $\mathrm{C}$ 2002Optimum ratio of dietary energy to protein for carp. Bulletine of the Japanese Society of Scientific Fisheries45: 983-987

[14] Day O and González P2003Soybean protein concentrate as a protein source for turbot Scophthalmus maximus L. Aquaculture Nutrition $6 ; 221-228$

[15] Echevarria MG, Henry PR, Ammerman CB and Rao PV 1988Efect time and dietaru Se concentr as sodium selenit on tissue Se uptake by sheep J. Anim Sci. 66:2299-2305 